International Journal of Social Science And Human Research

ISSN(print): 2644-0679, ISSN(online): 2644-0695

Volume 04 Issue 11 November 2021

DOI: $10.47191 / \mathrm{ijsshr} / \mathrm{v} 4-\mathrm{i} 11-43$, Impact factor-5.586

Page No: 3367-3371

\title{
Communicative Strategy, the Essence of the Terms of Communicative Tactics and Their Interpretation in World Linguistics
}

\author{
S. Barliboeva \\ PhD Student, Institute of Uzbek language, Literature and Folklore
}

\begin{abstract}
This article discusses communicative linguistics, a key branch of pragmatics. In particular, the concepts of communicative strategy, communicative tactics are explained, research is analyzed. Scientific views on the differences between the purpose of communication and the communication strategy are stated. The role of communicative tactics in political texts is highlighted.
\end{abstract}

KEYWORDS: Communicative strategy, communicative tactics, communication, pragmatics, purpose of communication, speaker, listener, politician.

\section{INTRODUCTION}

In linguistics, pragmatism has moved away from its "novelty". The reason is the need and interest in the field, a number of studies has begun to emerge. However, as a result of the study of pragmatics, new "aspects" of it have emerged, which indicates that there are still pressing issues to be studied in this area.

One of such areas is communicative linguistics, in particular, the study of communicative strategy and tactics, which in recent years has attracted a lot of attention in world linguistics, but in Uzbek linguistics there is still a great need for scientific considerations.

First, let's look at the essence of the concepts of strategy and tactics. An explanatory dictionary of the Uzbek language gives three meanings of the word "strategy".

1. As a military term. The Art of Warfare; general plan for war and military operations.

2. The science of warfare.

3. The art of leadership in the socio-political struggle in the figurative sense, as well as the art of accurate and forwardlooking management planning in general [1, p. 573].

Tactics are, first and foremost, a concept in the military field, as well as the specific ways and means, forms and methods of struggle to achieve the intended goal [1, p. 646].

We know that the terms can be widely used in other fields outside the relevant field of science, but its core meaning is still preserved. In pragmatics, too, communicative strategy is the "art of planning" based on its basic meaning, while communicative tactics are the tool chosen to achieve the intended purpose of communication.

\section{THE MAIN FINDINGS AND RESULTS}

What is the essence of the terms of communicative strategy, communicative tactics, and the role of these concepts in linguopragmatics? Linguist Shahriyor Safarov emphasizes that a speech act is the pronunciation of a certain sentence in a clear communication environment. The formation of the content of the speech act is the result of the "enrichment" of the meaning of the spoken sentence by the speaker and the listener in relation to the text of communication. The process of content formation in this way can be explained as follows:

The speaker

The linguistic system of speech

The Listener

Constant linguistic meaning

Changes in meaning in context 


\section{Communicative Strategy, the Essence of the Terms of Communicative Tactics and Their Interpretation in World Linguistics}

The above form testifies that the content of the content of a speech act and its occurrence are directly related to the purpose, the desire of the speaker to communicate [2, p. 81]:

In our opinion, too, the speech act is built entirely on the desire for communication. Only in this process of "construction" the text does not obey the "templates", the meaning changes in the context as a result of the speaking, listening and communicative environment. However, in our view, the purpose of communication does not help us to fully understand the concept of communicative strategy. These concepts are specific stages of speech activity. The reason is that the purpose of communication is a bit narrower than a communicative strategy. The goal of communication is the first "step", and the communication strategy is aimed at achieving this goal in a planned way. Speech activity can only take place within the framework of the purpose of communication without a communicative strategy. For example, knowing the price of a book by asking, "How much does a book cost?" Usually ends with a conversation about the price of a book. In this process, the speaker and the listener are usually equally active, and accordingly many changes in meaning occur. The communicative strategy is based on the addressee's plans in advance, the speaker is more active, the addressee initially has passive speech activity. Listener activity is directly related to the application of communicative strategy and tactics. As a result of the speech effect of the addressee, it is noticeable that the listener begins his speech activity after a certain time. For example, Alisher Kadyrov, the presidential candidate from the National Revival Party, addressed a meeting with voters. "The role of taxes is very important for the development of the country. Why shouldn't migrants go abroad today and pay taxes on their income? For the development of Uzbekistan, let's pay taxes. We'll see. That's good, of course. Money is coming. But this is money sent to your family, it is not taxed and this money is not used for the development of the country. So I would suggest: Let's be more patriotic, and migrants should pay their taxes for the development of the country [3]" he noted. The influence of the strategy chosen by the politician in making his proposal on taxation in communication some time later was reflected in the attitudes expressed by the audience, labor migrants. Of course, the speeches of many protesting against this proposal are a sign of different thinking in politics. But the politician must first pay more attention to its influence along with the word in the speech text. For example, the combination of the words "patriotic-migrant" and "money-tax" used by the politician has led to various misunderstandings, negative effects, and a lack of clear understanding of the purpose. Even the politician himself emphasizes this, saying that people misunderstand him [4]. At the same time, we can see the practical proof that the communicative strategy is a "weapon" of the politician in politics.

This means that the addressee becomes more active in the communication process using a communicative strategy. Although the addressee, i.e. the listener, is initially a passive communicator, the communication strategy and tactics serve to accelerate his or her subsequent activities. This can be seen in the link below.

\begin{tabular}{|l|l|l|}
\hline ADDRESSER & ADDRESSEE \\
\cline { 2 - 2 } & $\begin{array}{l}\text { Communicative strategy and } \\
\text { tactics }\end{array}$ & \\
\hline \hline
\end{tabular}

[2].

Sh.Safarov also noted that the content of the speech act is entirely related to the communicative intention of the speaker

Linguist M. Hakimov, on the other hand, said that the essence of the concept of a speech act reflects the communicative intention in the speaker's speech, and that the communicative intention is directly reflected in the speech as manifestations of speech acts, the strategy of expressing communicative intention is a central issue of linguistic pragmatics. The swimmer chooses this or that method of expression to explain his inner purpose to the listener. The selection process is directly the object of the stylistic direction of linguistics, the scientist says [5].

In world linguistics, the analysis of these concepts has been widely studied as a separate object of study.

Marina R. Zheltukhina - V. Maryana and others in the article "Linguopragmatic aspect of modern communication: main political media speech strategies and tactics in the USA and the UK" describes that communicative strategy means that the speaker predetermines individual ways to achieve a particular goal. It is also emphasized that the impact of speech is primarily related to planning and control, which are the main stages of speech activity. The article also cites the views of a number of scholars on communicative tactics.

In particular, Skarovodnikov says that communicative tactics are not a strategy, but a definite step towards achieving a goal, Ozhegov says, Swedes use communicative tactics as a means and technique of achieving a communicative strategy, in the view of Issers, communicative tactics are specific actions taken to achieve a goal [6].

Zalegdinova Aygul Rustamovna in her dissertation "Communicative strategies and tactics in a discursive talk show (on the material of Russian and English languages)" on the basis of the views of several linguists states that in cases, the effect of 


\section{Communicative Strategy, the Essence of the Terms of Communicative Tactics and Their Interpretation in World Linguistics}

speech is understood as the speech connection that is considered in its focus and motivational context. Any communication process will be directed to a goal that further regulates the activities of the interlocutor [Haslett 1987, Morley 1987, Blakar 1987, Kiseleva 1978, Rechevoe vozdeystvie 1990 et al.]. .]. The lexical meaning of the word "strategy" is based on the concept of planning (strategy is the art of long-term planning of a particular activity (economic, scientific, etc.)). The linguist argues that another linguist's strategy can be understood as certain cognitive operations related to discourse perception, i.e., strategies for understanding and interpreting meaning [Dyke, Kinch 1988].

Linguist Parshina Olga Nikolaevna describes the politician's desire for communication as follows:

a) encourage the addressee to vote in the election for a particular candidate, party, bloc, movement, etc.;

b) gaining trust or strengthening the image, "for the consent of the people";

c) encourage the addressee to agree with his opinion, views, accept them;

d) influencing the feelings of the addressee as a result of creating a certain emotional state;

e) provide the addressee with new information, knowledge, ideas on the topic of the speech and thereby express their position on a particular issue.

Based on all this, it can be said that in political speech, information is not simply given, it serves a purpose. It is about achieving certain goals by revealing the positive or negative attitude of the audience towards the topic of information, by making the necessary impact on it.

Linguist Issers Oksana Sergeevna: "In a communication strategy, the goal of the speech is to achieve long-term, concrete results that cover the entire scope of the communication process. First of all, the planning of a speech strategy includes the specific features of the speech communication process, the communication conditions, the personality of the communicators, as well as the implementation of this plan. In other words, a speech strategy is a set of verbal actions aimed at achieving a communicative goal [8].

According to the scientific view of D.A. Skulimovskaya, the main purpose of political speech is to convince the addressee and motivate him in this regard, based on the actions in which the addressee-politician is interested. This requires the speaker to use a specific speech plan. In this plan, a specific strategy is chosen to achieve the goals, and the means to achieve it is tactics [9].

Based on the definitions of communicative strategy given by S. Datsyuk, L.V. Tetova explains that communicative strategy is "the choice of this or that communication area, this or that communication tool, the type of interaction, so that the communication speech is based on one or more discourse measurements" [10].

Yu.Yu. Sukhanov believes that political speech should be understood as a multifaceted and complex phenomenon determined by the intentions of the communists, emphasizing that politicians should carefully choose communication strategies and tactics to implement political speech in the struggle for power [11].

Pointing out that there is no single interpretation of communication strategy in linguistics, A.P.Kryachkova enumerates a number of factors in defining it, including the creative implementation of a plan of action using linguistic (non-linguistic) means to achieve a communicative goal, unity of communicative and practical goals, and more [12].

Linguist Svetlana Vladimirovna Kryukova, based on her research in this area, says that it is important for a politician to use different communication tactics and strategies in public speech. In particular, it cites the following view of VB Kashkin on communicative strategy, i.e., part of a verbal behavior aimed at interacting with each other using a variety of verbal and nonverbal means to achieve a specific communicative goal. At the same time, in the opinion of GA Kopnina, "speech tactics - the speech movement in the implementation of a strategy at a certain stage" [13].

Elana Klemenova and Margarita Ereshchenko in their article "Communicative Strategies of Social Media Discourse" point out that communicative strategy is an optimal plan of communicative tactics in achieving the goal of communication [14].

In an article entitled "The influence of the communicative strategy on the degree of protectionability of texts in the Modern Political Discourse" co-authored by Elena Grass and other authors, the authors discuss I.N.Borisova's differences in concepts such as communicative strategy and communication intent. That is, if the intention of communication is the idea of the speaker, the communicative strategy is one of the choices of how to organize the communication [15].

In this regard, the terms "communicative strategy" and "communicative tactics" are almost not used in the scientific work of Uzbek linguistics, and instead such concepts as and ways to achieve the goal" are used. However, in our opinion, "communicative strategy" does not mean a communicative goal, in the process of a speech act, a communicative strategy is a long-term planning of a number of goals in advance, and the chosen method for achieving this goal is a tactic.

\section{CONCLUSION}

In our view, if we consider speech activity as a whole complex process, it is possible to consider the speech actions that take place step by step in the following order. First of all, there is a purpose to communication, which, as we have seen above, is expressed by some scholars in terms of "communicative intention", "purpose of communication", "idea of communication". The next step in 


\section{Communicative Strategy, the Essence of the Terms of Communicative Tactics and Their Interpretation in World Linguistics}

achieving the goal of communication is "planning," that is, choosing a communicative strategy. The chosen communication strategy plans the whole speech process, takes control of it. An attempt to directly implement a planned, controlled communication strategy is a communicative tactic. Communicative tactics can be conditionally called the "heart" of communication. The stronger it is, the final stage, i.e. the goal is achieved and the result is visible. We will consider this speech process on the basis of the following scheme.

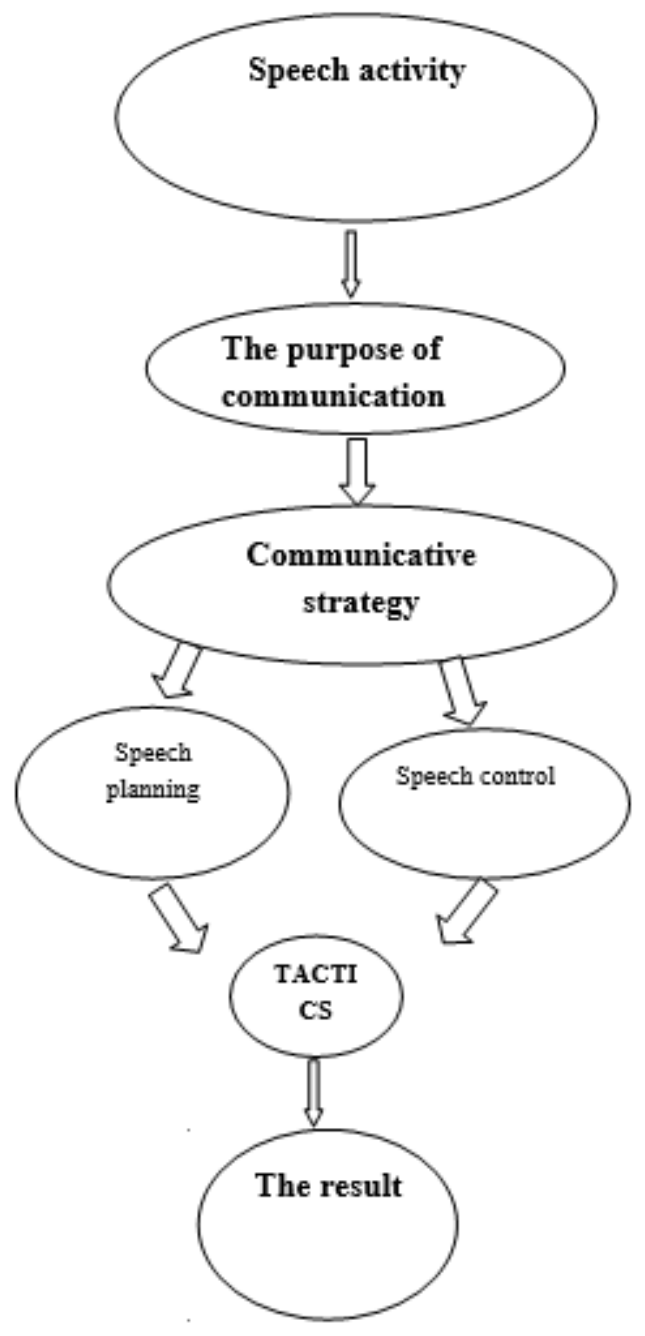

In-depth study of communication strategies and tactics in communicative linguistics, which is the main direction of pragma-linguistics, linguo-pragmatic analysis, classification, grouping, classification of individual types is one of the main goals of our dissertation.

\section{REFERENCES}

1) Annotated dictionary of the Uzbek language. The third volume. National Encyclopedia of Uzbekistan, 2020. - p. 573.

2) Ш.Сафаров. Прагмалингвистика Тошкент-2008. 318 б. 81-бет.

3) https://bugun.uz/2021/10/14/alisher-qodirov-migrantlarni-soliqqa-tortishni-taklif-qildi--video

4) https://daryo.uz/2021/10/21/odamlar-meni-tushunmayotgan-paytda-galabadan-umidvor-bolishim-mumkinmi-alisherqodirov/?utm_source=@daryo

5) Hakimov M. (2013) Basics of Uzbek prakmalinguistics. - Tashkent: Akademnashr. - pp. 20-21.

6) https://www.researchgate.net/publication/325212806_Linguopragmatic aspect_of modern_communication_Main politi cal_media_speech_strategies_and_tactics_in_the_USA_and_the_UK

7) Parshina Olga Nikolaevna. (2005) "Strategies and tactics of speech behavior of the modern political elite of Russia". Diss. Doctor of Philological Sciences. Saratov. - p. 7.

8) Issers Oksana Sergeevna. (2008) Communicative strategies and tactics of Russian speech. Ed. 5th. - Moscow: Publishing house LCI. - p. 288. 
Communicative Strategy, the Essence of the Terms of Communicative Tactics and Their Interpretation in World Linguistics

9) D. A. Skulimovskaya. Irkutsk, Russia. STRATEGIES AND TACTICS IN POLITICAL DISCOURSE (ON THE MATERIAL OF B. OBAMA'S SPEECHES.

10) Communication strategies in political discourse dit14.pdf

11) POLITICAL DISCOURSE 18277-19592-1-PB.pdf

12) IMPLEMENTATION OF THE STRATEGY 364-364-1-PB.pdf

13) http://www.discourseanalysis.org/ada22/st244.shtml

14) https://www.e3s-conferences.org/articles/e3sconf/pdf/2020/70/e3sconf_itse2020_16001.pdf

15) https://www.shs-conferences.org/articles/shsconf/pdf/2019/10/shsconf_cildiah2019_00047.pdf 